\title{
APLIKASI SISTEM RESIRKULASI PADA PENDEDERAN IKAN KAKAP PUTIH, Lates calcarifer KEPADATAN TINGGI
}

\author{
Gusti Ngurah Permana*\#\#, Zeny Pujiastuti"), Fakhrudin, Ahmad Muzaki*), \\ Ketut Mahardika*), dan Kukuh Adiyana*t) \\ *) Balai Besar Riset Budidaya Laut dan Penyuluhan Perikanan \\ Jl. Br. Gondol Kec. Gerokgak Kab. Buleleng, Kotak Pos 140, Singaraja, Bali 81101 \\ **) Pusat Riset Perikanan \\ Jl. Ragunan 20, Pasar Minggu, Jakarta Selatan 12540
}

(Naskah diterima: 24 Juni 2019; Revisi final: 29 Oktober 2019; Disetujui publikasi: 30 Oktober 2019)

\begin{abstract}
ABSTRAK
Teknologi resirkulasi (Recirculating aquaculture system [RAS]) dikembangkan untuk meningkatkan produktivitas benih ikan kakap putih. Tujuan dari penelitian ini untuk mengetahui pengaruh perbedaan kepadatan pada pendederan benih ikan kakap dengan sistem RAS. Penelitian ini menggunakan sistem RAS dengan 12 bak dengan volume $1,0 \mathrm{~m}^{3}$ yang terbagi dalam dua modul dengan masing-masing modul terdiri atas enam bak. Untuk perbandingan digunakan sistem sirkulasi yang mengadopsi teknologi yang ada di masyarakat menggunakan tiga bak beton dengan volume $1 \mathrm{~m}^{3}$. Benih ikan kakap putih yang dipergunakan memiliki panjang rata-rata: $2,87 \mathrm{~cm} \pm 0,18 \mathrm{~cm}$ dan bobot rata-rata: $0,39 \pm 0,07 \mathrm{~g}$. Perlakuan menggunakan perbedaan kepadatan yaitu (A) 3.000 ekor $/ \mathrm{m}^{3}\left(1,17 \mathrm{~kg} / \mathrm{m}^{3}\right)$; (B) $4.500 \mathrm{ekor} / \mathrm{m}^{3}\left(1,75 \mathrm{~kg} / \mathrm{m}^{3}\right)$; dan (C) sirkulasi $1.500 \mathrm{ekor} / \mathrm{m}^{3}\left(0,62 \mathrm{~kg} / \mathrm{m}^{3}\right)$. Parameter yang diamati meliputi: pertumbuhan, sintasan, kualitas air, dan pada akhir penelitian, sampel darah diambil untuk menentukan kesehatan ikan yang berhubungan dengan parameter haematokrit darah. Analisis data secara deskriptif dan uji t test. Hasil penelitian menunjukkan bahwa perbedaan padat penebaran pada sistem RAS dan sirkulasi secara signifikan tidak menunjukkan perbedaan $(P>0,05)$ pertumbuhan panjang dan bobot benih. Sintasan tertinggi diperoleh pada kelompok ikan kontrol, diikuti dengan kelompok ikan dengan kepadatan $3.000 \mathrm{ekor} / \mathrm{m}^{3}$ dan terendah pada kelompok ikan dengan kepadatan $4 ., 500 / \mathrm{m}^{3}$ ekor. Nilai hematokrit dalam darah lebih tinggi $(\mathrm{P}<0,05)$ ditunjukkan dari kelompok ikan dengan kepadatan yang lebih rendah. Hasil tersebut menunjukkan bahwa aplikasi sistem resirkulasi pada pendederan ikan kakap putih dapat dilakukan dengan penerapan kepadatan 3.000 ekor $/ \mathrm{m}^{3}\left(31,04 \mathrm{~kg} / \mathrm{m}^{3}\right)$.
\end{abstract}

\section{KATA KUNCl: kakap putih; pendederan; recirculating aquaculture system; sintasan}

ABSTRACT: Application of recirculating aquaculture system (RAS) on high density nursery of barramundi (Lates calcarifer Bloch) juvenile. By: Gusti Ngurah Permana, Zeny Pujiastuti, Fakhrudin, Ahmad Muzaki, Ketut Mahardika, and Kukuh Adiyana

Recirculating aquaculture system (RAS) has been developed to increase the productivity of barramundi nursery. This study used 12 tanks with a volume of $1.0 \mathrm{~m}^{3}$ each. The tanks were grouped into two modules, each module consisted of six tanks. As a comparison, a circulation system adopted by the local community was used which consisted of three concrete tanks with a volume of $1 \mathrm{~m}^{3}$. Barramundi juveniles with an average length: $2.87 \mathrm{~cm} \pm 0.18 \mathrm{~cm}$ and an average weight of $0.39 \pm 0.07 \mathrm{~g}$ ) were used in the experiment. The treatments were differences in stocking densities: $3,000 \mathrm{fish} / \mathrm{m}^{3}\left(1.17 \mathrm{~kg} / \mathrm{m}^{3}\right) ; 4,500 \mathrm{fish} / \mathrm{m}^{3}\left(1.75 \mathrm{~kg} / \mathrm{m}^{3}\right)$; and control 1,500 fish $/ \mathrm{m}^{3}\left(0.62 \mathrm{~kg} / \mathrm{m}^{3}\right)$. Data collected included growth of survival and water quality variables (temperature, salinity, $\mathrm{DO}, \mathrm{pH}$, nitrite, $\mathrm{NH}_{3}$, total bacteria/ vibrio) and blood hematocrit. The results of this study showed that fish densities $\left(4,500 ; 3,000 ;\right.$ and $\left.1,500 \mathrm{fish} / \mathrm{m}^{3}\right) \mathrm{did}$ not affect fish growth. However, the survival rate was significantly different $(P<0.05)$ among the treatments. The

\footnotetext{
\# Korespondensi: Balai Besar Riset Budidaya Laut dan

Penyuluhan Perikanan. JI. Br. Gondol Kec. Gerokgak

Kab. Buleleng, Kotak Pos 140, Singaraja, Bali 81101, Indonesia.

Tel. + 6236292272

E-mail: gustipermana@gmail.com
} 
values of hematocrit were significantly $(P<0.05)$ higher at the density of $46.56 \mathrm{~kg} / \mathrm{m} 3$. These results suggest that the RAS application can sustain a nursery density of Barramundi up to 3,000 ind./ $/ \mathrm{m}^{3}\left(31.04 \mathrm{~kg} / \mathrm{m}^{3}\right)$.

\section{KEYWORDS: barramundi; nursery; survival; recirculating aquaculture systems}

\section{PENDAHULUAN}

Sistem resirkulasi memberikan metode produksi alternatif yang mampu mengontrol kualitas air, salinitas, penyakit, persediaan air, ketersediaan lahan, sebagai alternatif pemeliharaan ikan yang lebih efektif dari segi biaya (Chen et al., 1997). Sistem resirkulasi telah banyak digunakan di laboratorium penelitian dan universitas di seluruh negeri, tetapi penggunaan komersial terbatas pada produk bernilai relatif tinggi (Malone, 2013).

Budidaya kakap putih yang terus berkembang memerlukan penyediaan benih ikan kakap putih yang tepat mutu, ukuran, jumlah, dan waktu. Masalah utama yang dihadapi dalam produksi benih kakap adalah adanya infeksi virus (VNN atau iridovirus). Seringkali infeksi virus tersebut jarang menimbulkan kematian, tetapi hanya menjadi host/carrier. Salah satu upaya peningkatan produksi benih kakap putih melalui usaha pendederan yang intensif dengan penerapan recirculation aquaculture systems (RAS). Sistem ini digunakan untuk pemeliharaan ikan dengan kepadatan tinggi dalam sebuah tangki dengan lingkungan terkontrol (Timmons et al., 2002).

Teknologi resirkulasi telah dibahas secara mendalam oleh Timmons \& Ebeling (2007). Pendekatan teknologi utama yang digunakan dalam desain saat ini yang dapat berkisar hampir 1-400 m³. Akan tetapi, peningkatan kepadatan (stocking) dapat menyebabkan berkurangnya efisiensi filter biologis dengan aplikasi hyper-intensive recirculating aquaculture system ikan nila (Gullian-Klanian \& Arámburu-Adame, 2013) dan ikan turbot, Scophthalmus maximus (Li et al., 2013). Menurut Drengstig \& Bergheim (2013), aplikasi teknologi recirculating aquaculture system (RAS) pada kegiatan pendederan, dapat digunakan untuk menjaga kualitas air dan meminimalkan risiko terjadinya serangan penyakit. Kelebihan dari sistem ini adalah padat tebar tinggi, serta lingkungan budidaya lebih terkontrol. Sistem resirkulasi juga lebih ramah lingkungan yaitu dengan pemanfaatan kembali air yang digunakan, sehingga tidak ada penggantian air selama kegiatan budidaya (Timmons et al., 2002).

Aplikasi teknologi RAS pada budidaya perikanan air laut di Indonesia masih belum banyak diketahui, terutama mengenai kebutuhan akan protein skimmer, biofilter, kualitas air, dan respons dari ikan kakap putih. Tujuan dari penelitian ini untuk mengetahui pengaruh perbedaan kepadatan pada pendederan benih ikan kakap dengan sistem RAS.

\section{BAHAN DAN METODE}

\section{Hewan Uji}

Benih ikan kakap putih sehat ukuran 2,87 cm \pm $0,18 \mathrm{~cm}$ dengan bobot rata-rata: 0,39 $\pm 0,07 \mathrm{~g}$; ikan yang dipergunakan dalam penelitian ini berasal dari hasil pembenihan di Balai Besar Riset Budidaya Laut dan Penyuluhan Perikanan (BBRBLPP). Ikan-ikan tersebut diaklimatimasi terlebih dahulu selama dua hari di bak penelitian.

\section{Persiapan Sistem RAS}

Pada tahap ini dilakukan desinfeksi air (klorinasi, deklorinasi), operasional biofilter dengan terlebih dahulu melakukan penumbuhkan bakteri Bacillus sp., Nitrobacter sp., dan Nitrosomonas sp. Untuk meningkatkan fungsi sistem menggunakan protein skimmer, water heater, dan otomatisasi pompa air.

\section{Desain Penelitian}

Penelitian ini menggunakan 12 bak pemeliharaan dengan volume $1 \mathrm{~m}^{3}$ yang terbagi dalam dua modul dengan masing-masing ulangan terdiri atas enam bak pemeliharaan. Sebanyak dua bak volume $1 \mathrm{~m}^{3}$ digunakan untuk mekanikal filter dan biofilter. Desain mekanikal filter menggunakan keranjang (2292p green leaf) ukuran $631 \mathrm{~mm} \times 414 \mathrm{~mm} \times 217 \mathrm{~mm}$ yang disusun tiga tingkat (Gambar 1). Desain biofilter menggunakan bioball dan bioblock. Penambahan skimmer pada bak biofilter (Gambar 1). Sebagai pembanding digunakan sistem sirkulasi, mengadopsi teknologi yang ada di masyarakat menggunakan tiga bak beton dengan volume $1 \mathrm{~m}^{3}$.

\section{Perlakuan}

Penelitian menggunakan perlakuan perbedaan padat tebar yaitu (A) $3.000 \mathrm{ekor} / \mathrm{m}^{3}\left(1,17 \mathrm{~kg} / \mathrm{m}^{3}\right)$; (B) 4.500 ekor $/ \mathrm{m}^{3}\left(1,75 \mathrm{~kg} / \mathrm{m}^{3}\right)$; dan (C) sistem sirkulasi yang berkembang di masyarakat dengan kepadatan $1.500 \mathrm{ekor} / \mathrm{m}^{3}\left(0,62 \mathrm{~kg} / \mathrm{m}^{3}\right)$. Penelitian ini dilakukan selama 28 hari. Untuk menjaga stabilitas suhu ditempatkan pemanas otomastis (automatic heater). Sterilisasi air tandon mengggunakan sinar UV (ultraviolet) untuk mengurangi muatan organik dan bakteri merugikan. Pakan komersial (merk otohime dan kaio) 


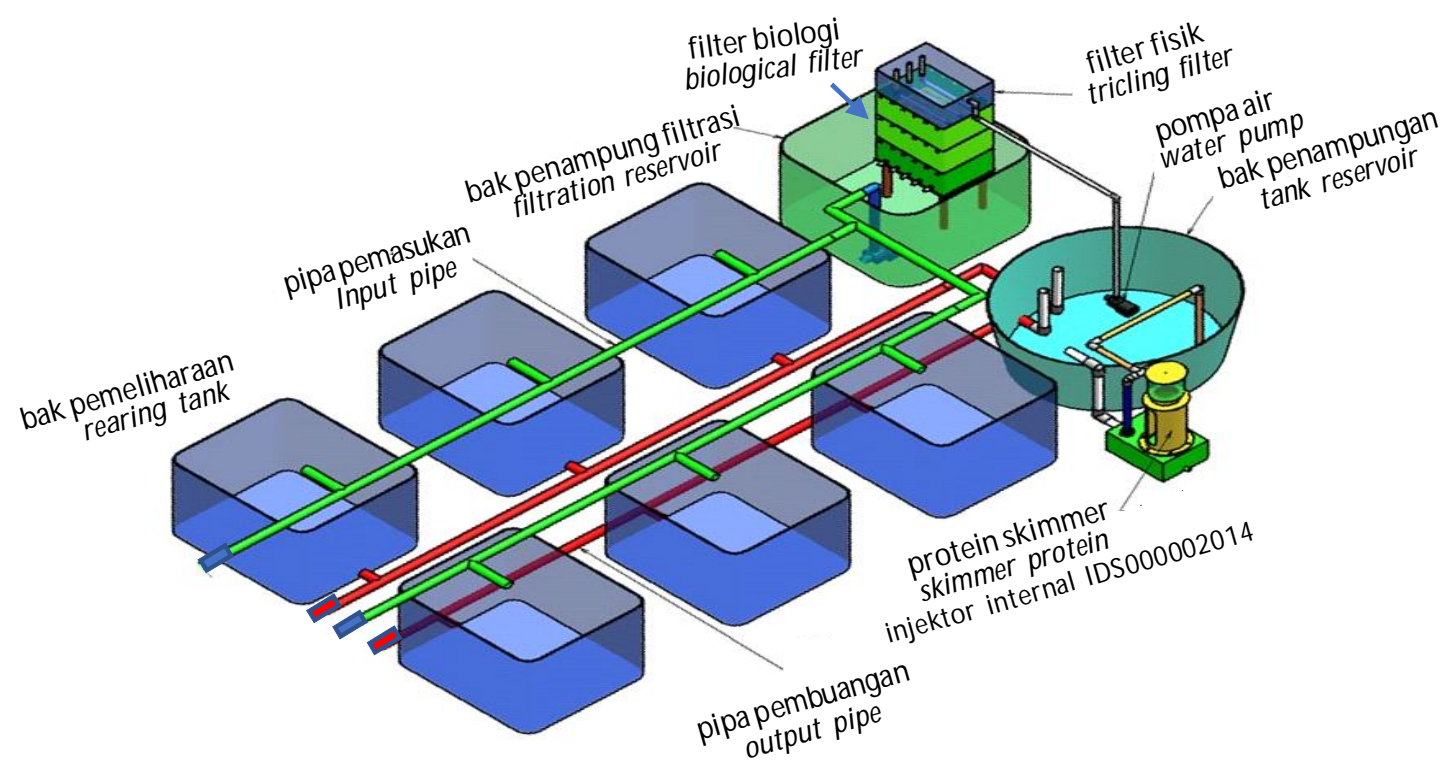

Gambar 1. Model hatchery resirkulasi sederhana untuk pendederan kakap putih.

Figure 1. Simple model of recirculating aquaculture system (RAS) of barramundi nursery.

yang dipergunakan dengan dosis adlibitum. Pemisahan ukuran atau gradding tidak dilakukan selama pemeliharaan. Persentase kanibalisme dihitung dari jumlah populasi $=$ jumlah mati + kanibalisme. Sampling pertumbuhan dilakukan setiap tujuh hari sekali untuk melihat performansi pertumbuhan. Pembuangan endapan kotoran di dasar dilakukan pada pagi dan sore hari sekitar $5 \%$

\section{Parameter Kualitas Air}

Suhu, salinitas, DO, dan $\mathrm{pH}$ air di setiap tangki diukur setiap hari menggunakan DO meter YSI-55 $(\mathrm{OH}$, USA) dan pH meter Cyber-scan 30 (IL, USA). Analisis nitrit (NO2), dan amoniak $\left(\mathrm{NH}_{3}\right)$ dilakukan setiap empat hari.

Pengambilan darah dilakukan sebanyak dua kali pada awal dan akhir penelitian. Sebelum pengambilan darah, ikan terlebih dahulu dibius menggunakan eugenol 0,05 mL/L. Sampel darah diambil menggunakan syrenge $1 \mathrm{~mL}$ yang telah dibilas larutan Heparin sodium 5.000 iu, dan dimasukkan ke dalam tabung Eppendorf. Analisis menggunakan Hematocritkapillaren dan dicentrifugasi 1.500 rpm.

\section{Analisis Data}

Laju pertumbuhan dilakukan dengan pencatatan hasil pengukuran panjang dan bobot pada awal penelitian dan pada akhir penelitian. Laju pertumbuhan dihitung dengan rumus Zonneveld et al. (1991):

$$
\mathrm{SGR}=\frac{(\ln W \mathrm{t}-\ln \mathrm{W} 0)}{\mathrm{t}} \times 100 \%
$$

di mana:

$\mathrm{SGR}=$ laju pertumbuhan harian $(\%)$

$\mathrm{Wt}=$ bobot ikan akhir $(\mathrm{g})$

W0 $=$ bobot ikan awal $(\mathrm{g})$

$\mathrm{t}=$ waktu pemeliharaan (hari)

Data rata-rata pertumbuhan, pertumbuhan panjang, dan sintasan yang diperoleh selama penelitian disajikan dalam bentuk tabel. Analisis data secara kuantitatif menggunakan uji t test. Semua perhitungan dilakukan dengan software SPSS 14.0.

\section{Analisis Usaha}

Analisis usaha pendederan kakap putih untuk mengetahui sampai di manakeberhasilan telah dicapai. $\mathrm{R} / \mathrm{C}$ rasio (revenuecost ratio). $\mathrm{R} / \mathrm{C}$ rasio merupakan rasio atau nisbah antara penerimaan total dan biaya produksi total yang secara matematis dinyatakan dengan rumus:

$$
\mathrm{R} / \mathrm{C} \text { ratio }=\mathrm{TRTC}
$$

Usaha atau bisnis dinyatakan layak (feasible) jika $\mathrm{R} / \mathrm{C}$ rasio $>0$. Jika $\mathrm{R} / \mathrm{C}$ rasio $<0$ usaha atau bisnis dinyatakan tidak layak, sedangkan jika $\mathrm{R} / \mathrm{C}$ rasio $=0$ usaha dinyatakan impas (Fitriadi \& Nurmalina, 2008).

\section{HASIL DAN BAHASAN}

\section{Pertumbuhan}

Pertumbuhan panjang dan bobot benih ikan kakap putih yang dipelihara pada sistem resirkulasi dengan kepadatan berbeda tidak berbeda nyata $(P>0,05)$. Pertumbuhan panjang dan bobot akhir dari benih kakap

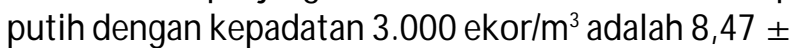


$1,21 \mathrm{~cm}$ dan $10,26 \pm 4,40 \mathrm{~g}$; dan kepadatan 4.500 ekor $/ \mathrm{m}^{3}$ memiliki panjang dan bobot rata-rata sebesar $8,29 \pm 1,12 \mathrm{~cm}$ dan $9,35 \pm 3,84 \mathrm{~g}$. Hasil pada sistem sirkulasi kepadatan $\left(1.500 \mathrm{ekor} / \mathrm{m}^{3}\right)$, rata-rata panjang akhir adalah 8,38 $\pm 0,11 \mathrm{~cm}$ dan bobot akhir sebesar, 10,56 $\pm 3,18 \mathrm{~g}$ (Gambar 2; Tabel 1).

Hasil tersebut menunjukkan bahwa ketersediaan ruang bukan menjadi faktor pembatas pertumbuhan pada pendederan kakap putih di bak dengan sistem resirkulasi. Hal ini berbeda dengan yang disampaikan oleh Riche et al. (2013) menurunnya pertumbuhan seiring dengan meningkatnya kepadatan merupakan sebuah gejala yang normal dan penebaran yang tinggi, ruang gerak ikan menjadi sempit sehingga pertumbuhan ikan akan terhambat.

Kepadatan yang tinggi juga mempercepat penurunan kualitas air budidaya, akibat akumulasi metabolit dan sisa pakan, sehingga berpengaruh besar terhadap pertumbuhan (Zonneveld et al., 1991).

\section{Sintasan}

Sintasan yang diperoleh pada pendederan benih kakap putih dengan kepadatan yang berbeda menunjukkan hasil yang berbeda nyata $(P<0,05)$. Nilai sintasan setelah penelitian selama 28 hari diperoleh hasil tertinggi pada kontrol (C) $82,62 \pm 1,75 \%$ kemudian perlakuan (A) $48,80 \pm 1,10 \%$ dan perlakuan (B) sebesar 42,7 \pm 2,85\% (Gambar 3a). Rendahnya sintasan pada perlakuan sistem RAS dapat disebabkan oleh tingginya kanibalisme dan penurunan kualitas air media karena sistem biofilter belum bekerja optimal (Tabel 2).

Kanibalisme sangat erat hubungannya dengan ukuran dan padat tebar terutama pemanfataan ruang gerak pada media pemeliharaan ikan. Persentase kanibalisme tertinggi terlihat pada padat penebaran $4.500 \mathrm{ekor} / \mathrm{m}^{3}$ sebesar 39,91\% diikuti padat penebaran $3.000 \mathrm{ekor} / \mathrm{m}^{3}$ sebesar $33,18 \%$ dan sirkulasi 1.500 ekor $/ \mathrm{m}^{3}$ sebesar $11,00 \% \mathrm{Hal}$ ini dapat disebabkan
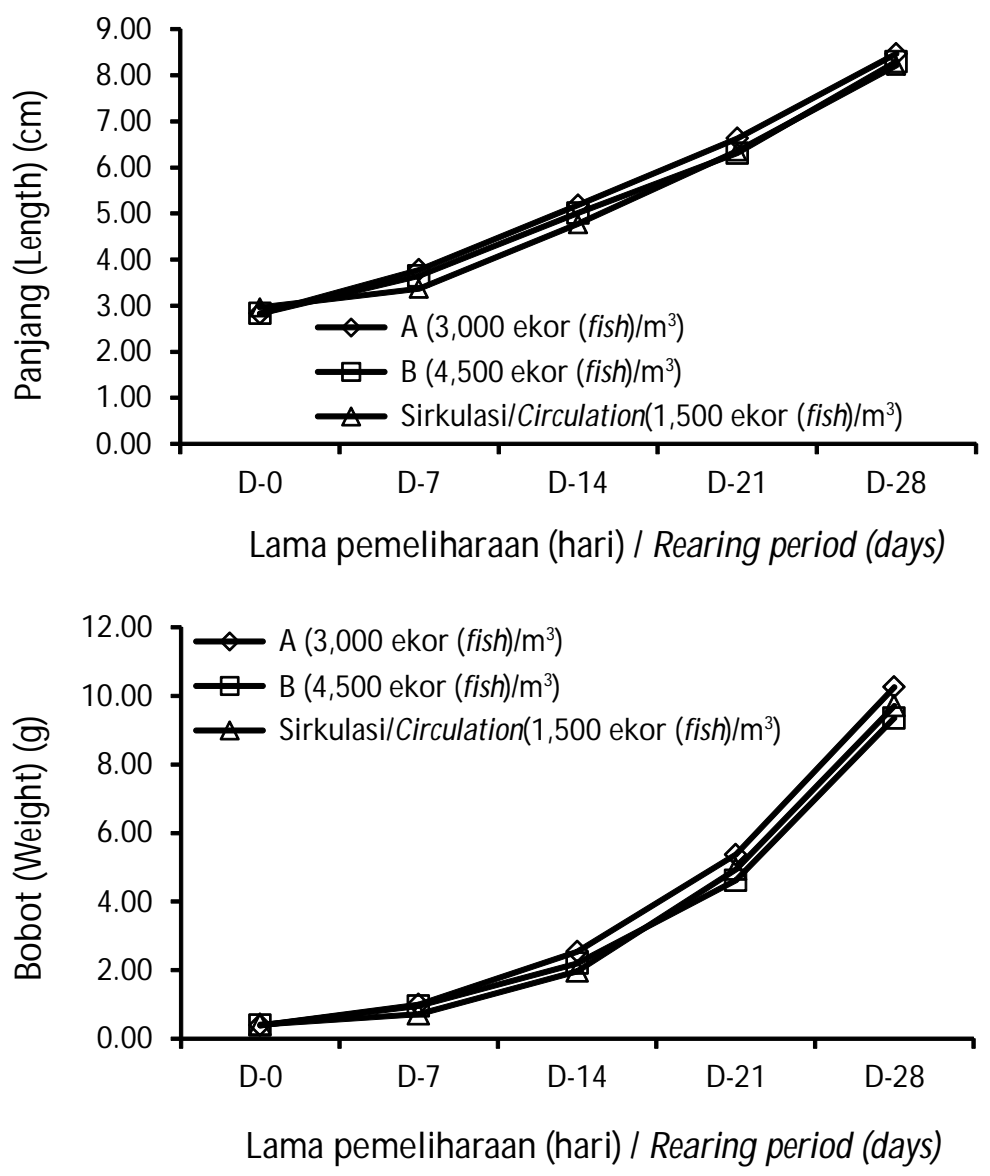

Gambar 2. Pertumbuhan panjang (A) dan bobot (B) benih kakap putih selama pemeliharaan.

Figure 2. Total length $(A)$ and body weight $(B)$ of juvenile barramundi during experiment. 
Tabel 1. Pengaruh perbedaan kepadatan penebaran pada pendederan ikan kakap putih (Lates calcarifer) dengan sistem RAS.

Table 1. The effects of different stocking densities to the growth of barramundi juvenile in the RAS.

\begin{tabular}{|c|c|c|c|}
\hline \multirow{3}{*}{$\begin{array}{l}\text { Parameter pertumbuhan } \\
\text { Growth parameters }\end{array}$} & \multicolumn{3}{|c|}{ Kepadatan (Stocking density) $\left(\mathrm{kg} \mathrm{m}^{3}{ }^{3}\right)$} \\
\hline & \multicolumn{2}{|c|}{$\begin{array}{c}\text { Resirkulasi } \\
\text { Recirculating system }\end{array}$} & \multirow{2}{*}{$\begin{array}{c}\begin{array}{c}\text { Sirkulasi } \\
\text { Circulating system }\end{array} \\
\begin{array}{c}1.500 \mathrm{ekor} / \mathrm{m}^{3} \\
\left(0.60 \mathrm{~kg} / \mathrm{m}^{3}\right)\end{array}\end{array}$} \\
\hline & $\begin{array}{c}3.000 \text { ekor } / \mathrm{m}^{3} \\
\left(1.14 \mathrm{~kg} / \mathrm{m}^{3}\right)\end{array}$ & $\begin{array}{c}4.500 \text { ekor } / \mathrm{m}^{3} \\
\left(1.74 \mathrm{~kg} / \mathrm{m}^{3}\right)\end{array}$ & \\
\hline Panjang awal (Initial length) (cm) & $2.82 \pm 0.18$ & $2.83 \pm 0.12$ & $2.97 \pm 0.25$ \\
\hline Panjang akhir (Mean final length) (cm) & $8.47 \pm 1.21^{\mathrm{a}}$ & $8.29 \pm 1.12^{\mathrm{a}}$ & $8.38 \pm 0.11^{\mathrm{a}}$ \\
\hline Pertumbuhan panjang mutlak (M ean length gain) (cm) & $5.65 \pm 0.33^{\mathrm{a}}$ & $5.47 \pm 0.54^{\mathrm{a}}$ & $5.41 \pm 0.11^{\mathrm{a}}$ \\
\hline $\begin{array}{l}\text { Laju pertumbuhan panjang spesifik }\left(\% \text { har }^{-1}\right) \\
\text { Specific arowth rate }\left(\% \text { dav }{ }^{-1}\right)\end{array}$ & $3.92 \pm 0.13^{\mathrm{a}}$ & $3.83 \pm 0.23^{\mathrm{a}}$ & $3.70 \pm 0.04^{\mathrm{a}}$ \\
\hline Bobot awal (Initial weight) (g) & $0.38 \pm 0.01$ & $0.39 \pm 0.06$ & $0.41 \pm 0.09$ \\
\hline Bobot akhir (M ean final weight) $(\mathrm{g})$ & $10.26 \pm 4.40^{\mathrm{a}}$ & $9.35 \pm 3.84^{\mathrm{a}}$ & $10.56 \pm 3.18^{a}$ \\
\hline Pertumbuhan bobot mutlak (M ean weight gain) (g) & $9.88 \pm 1.73^{\mathrm{a}}$ & $8.97 \pm 1.75^{\mathrm{a}}$ & $8.88 \pm 1.20^{\mathrm{a}}$ \\
\hline $\begin{array}{l}\left.\text { Laju pertumbuhan bobot spesisfik (\%hari }{ }^{-1}\right) \\
\text { Specific arowth rate }\left(\% \text { dav }{ }^{-1}\right)\end{array}$ & $11.73 \pm 0.54^{\mathrm{a}}$ & $11.29 \pm 0.64^{\mathrm{a}}$ & $11.60 \pm 0.20^{\mathrm{a}}$ \\
\hline Sintasan (Survival rate) $(\%)$ & $48.80 \pm 1.10$ & $42.7 \pm 2.85$ & $82.62 \pm 1.75$ \\
\hline Biomas awal (Initial biomass) (kg) & $1.14 \pm 0.04$ & $1.74 \pm 0.60$ & $0.60 \pm 0.08$ \\
\hline Biomas akhir (Harvest biomass (kg) & $14.489 \pm 1.91$ & $11.738 \pm 1.48$ & $12.93 \pm 1.13$ \\
\hline
\end{tabular}

adanya perbedaan ukuran besar, sedang, dan kecil ikan di akhir penelitian. Upaya yang dapat dilakukan adalah pemisahan ukuran (grading) di mana ukuran ikan yang tidak seragam dapat menyebabkan kanibalisme, kompetisi pakan, oksigen, dan ruang. grading dilakukan ketika ukuran ikan dalam satu bak pemeliharaan sudah jelas nampak perbedaan ukurannya (Gambar 3b).

Padat penebaran merupakan salah satu faktor yang berpotensi memengaruhi sintasan dan performansi ikan. Dengan demikian, penggunaan kepadatan yang tepat bisa meningkatkan profitabilitas sistem budidaya (Fairchild \& Howell, 2001). Namun, kepadatan penebaran yang memadai bergantung pada berbagai faktor seperti umur sistem, ukuran ikan, kadar oksigen terlarut, jenis dan desain sistem pemeliharaan (El-sayed \& Mamdouh, 2008). Hasil penelitian menunjukkan bahwa kepadatan penebaran tinggi menghasilkan limbah nitrogen dari sisa pakan dan kotoran sisa pakan dan feses ke dalam sistem. Tren mortalitas terlihat pada hari ke-12 (Gambar 4) yang mengindikasikan kekuatan sistem sudah tidak mampu menahan beban limbah yang dihasilkan.

\section{Kualitas Air}

Padat penebaran ikan yang tinggi, air juga dapat menjadi cepat tercemar dan membuat konsentrasi nitrit dan amoniak menjadi tinggi. Siklus nitrogen juga terjadi dalam sistem resirkulasi yang merupakan salah satu elemen penting dalam sistem resirkulasi. Bakteri berkembang pada spon, bioball, dan bioblok sebagai media biofilter, dan memecah unsur hara dalam air menjadi bentuk yang dapat dimanfaatkan oleh bakteri.

Tidak ada perbedaan yang signifikan pada suhu, DO, dan $\mathrm{pH}$ di antara perlakuan dengan kepadatan yang berbeda (Tabel 2). Dissolved oxygen (DO) lebih tinggi pada kepadatan yang lebih rendah (Sharma \& Chakrabarti, 2003). Suhu air pada perlakuan RAS sangat konstan dibandingkan dengan kontrol berkisar antara $27,02^{\circ} \mathrm{C}-31,9^{\circ} \mathrm{C}$ selama periode pertumbuhan 28 hari. Amonia $\left(\mathrm{NH}_{3}\right)$, nitrit $\left(\mathrm{NO}_{2}\right)$, dan $\mathrm{pH}$ merupakan parameter kualitas air yang berperan penting pada pendederan kakap sistem RAS. Nilai amonia dan nitrit secara paralel terjadi peningkatan pada hari ke-12 pada kepadatan $4.500 \mathrm{ekor} / \mathrm{m}^{3}$, hal ini mengindikasikan bahwa sistem biofilter mampu bertahan sampai 12 hari. Hal ini berkorelasi dengan meningkatnya total bakteri dan vibrio (Gambar 5). Untuk itu, perlu perbaikan sistem biofilter dalam menunjang mekanisme sistem RAS yang berkesinambungan.

Daya dukung RAS sangat kuat dipengaruhi oleh kemampuan sistem untuk membuang limbah nitrogen, terutama dalam bentuk amonia dan nitrat. Kapasitas RAS untuk menghilangkan limbah nitrogen tergantung pada kapasitas kompartemennya. Sebagaimana 

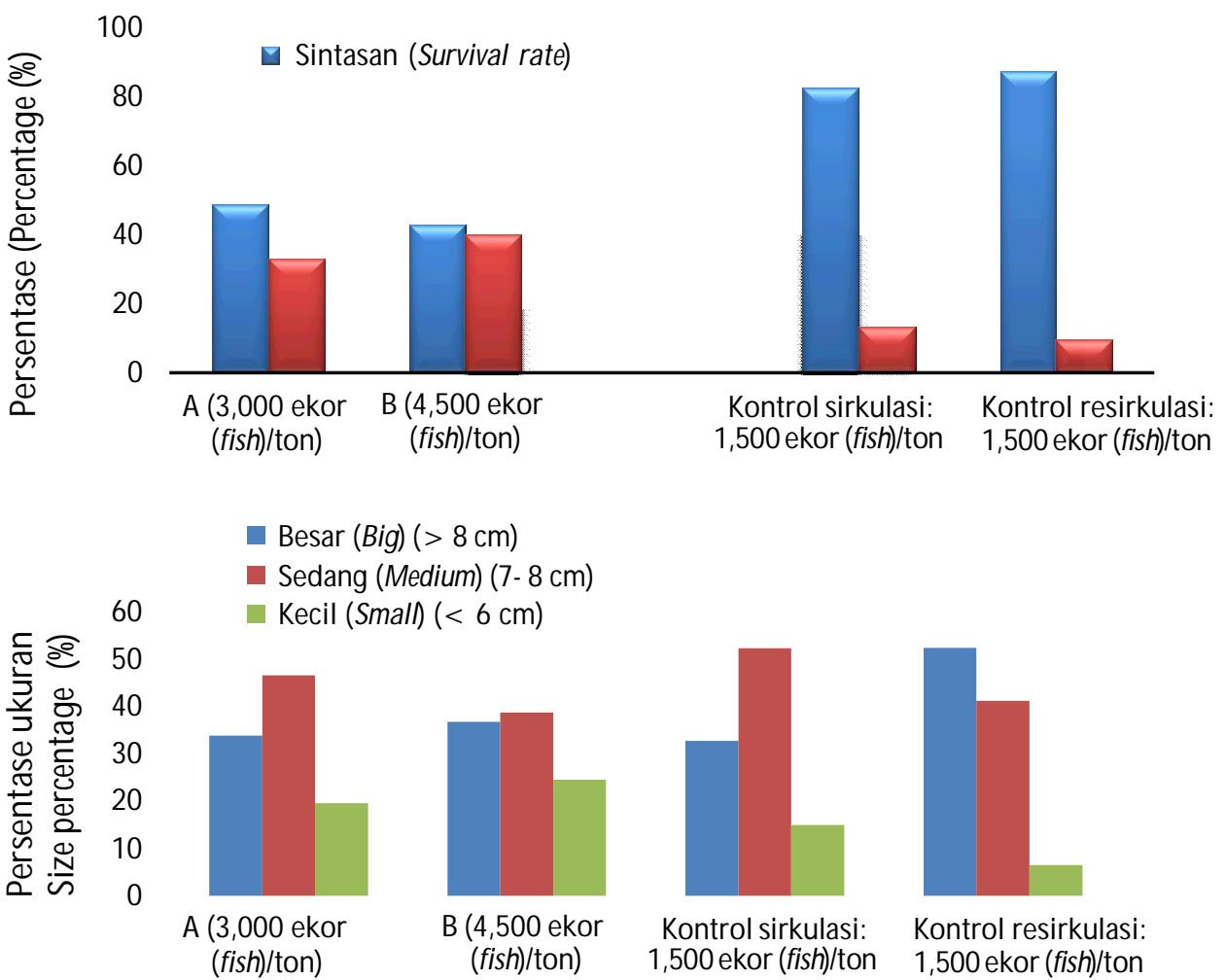

Gambar 3. Sintasan dan persentase kanibalisme benih (a); persentase perbedaan ukuran (b) ikan kakap putih, L. calcarifer yang dipelihara di sistem RAS dengan kepadatan berbeda.

Figure 3. Survival rate and canibalism (a); size different percentages (b) of juvenile barramundi, L. calcarifer during the experiment of different density in the RAS system.
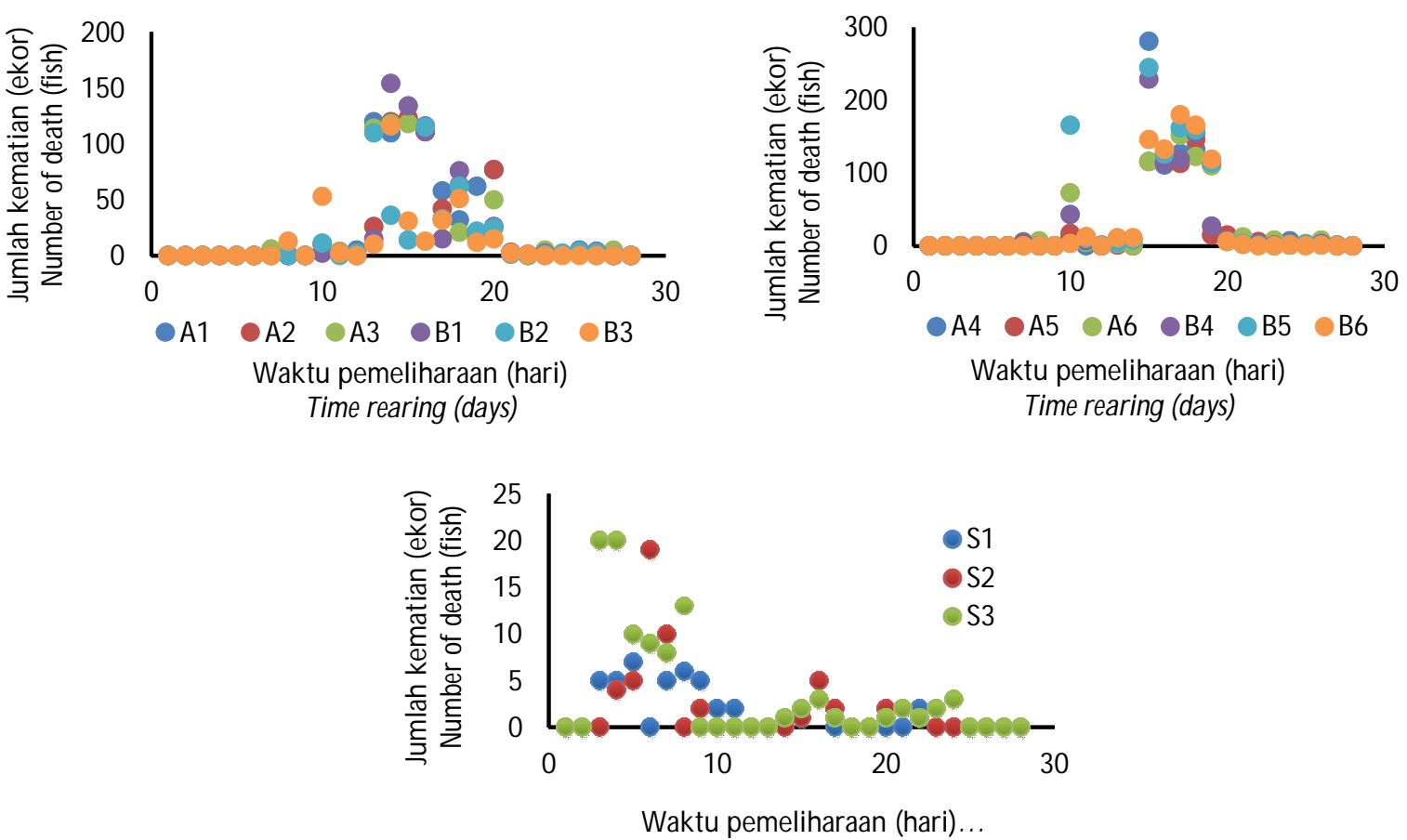

Gambar 4. Tren kematian ikan kakap putih, L. calcarifer yang dipelihara di sistem RAS dengan kepadatan berbeda.

Figure 4. Mortality trend of juvenile barramundi, L. calcarifer during the experiment in he RAS system. 
Tabel 2. Nilai parameter kualitas air pada pendederan ikan kakap putih, L. calcarifer yang dipeliharan pada sistem RAS dengan kepadatan yang berbeda

Table 2. The value of water quality parameters in the RAS system during the experiment

\begin{tabular}{lccc}
\hline \multirow{2}{*}{ Variabel (Nariables) } & \multicolumn{3}{c}{ Perlakuan (Treatment) } \\
\cline { 2 - 4 } & A & B & C \\
\hline Suhu (Temperature) $\left({ }^{\circ} \mathrm{C}\right)$ & $29.5 \pm 0.4$ & $29.5 \pm 0.4$ & $28.1 \pm 3.8$ \\
Salinitas (Salinity) (ppt) & $25.0 \pm 1.0$ & $25.0 \pm 1.0$ & $25.0 \pm 1.0$ \\
Oksigen terlarut (Dissolved oxygen) (mg/L) & $3.9 \pm 0.5$ & $3.5 \pm 0.4$ & $4.4 \pm 0.2$ \\
pH & $8.3 \pm 1.0$ & $8.2 \pm 1.05$ & $8.1 \pm 0.0$ \\
Amonia (Ammonia) (mg/L) & $0.05-7.09$ & $0.05-12.09$ & $0.05-3.5$ \\
Nitrit (Nitrite) (mg/L) & $>0.1-3$ & $>0.1-13$ & $>0.1-3$ \\
\hline
\end{tabular}
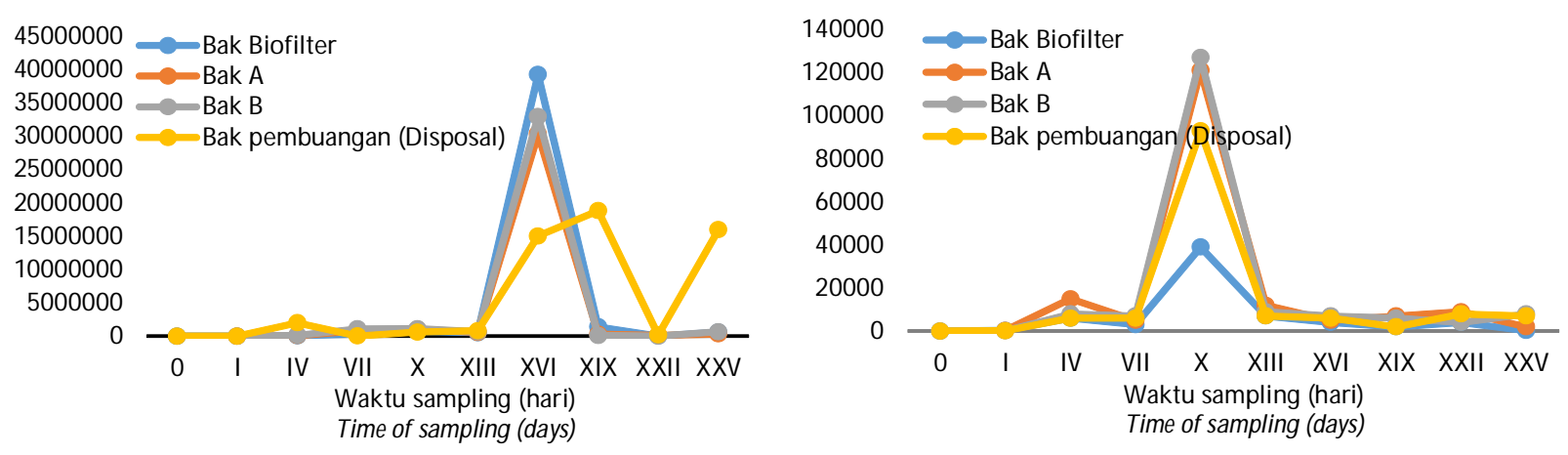

Gambar 5. Keragaan total bakteri (a) dan total vibrio (b) di dalam biofilter selama penelitian.

Figure 5. Total bacterial (a) and vibrio performance (b) in the biofilter during the experiment.

dinyatakan oleh Helfrich \& Libey (1990); Schreier et al. (2010) kapasitas biofilter dipengaruhi oleh beberapa faktor, termasuk luas permukaan kompartemen biofilter, diversity mikroba, filter mekanis, dan debit output resirkulasi. Hasil penelitian ini menunjukkan bahwa kepadatan tebar optimal di RAS dapat ditingkatkan dengan meningkatkan kapasitas biofilernya.

\section{Hematokrit}

Pengamatan nilai hematokrit dilakukan untuk melihat perubahan yang terjadi pada pemeliharaan ikan kakap putih dengan sistem RAS. Rata-rata nilai hematokrit benih ikan kakap putih selama penelitian dapat dilihat pada Tabel 3. Hematokrit dapat menjadi indikator untuk menentukan keadaan kesehatan ikan atau ikan dalam keadaan stres (Shiver \& Grove, 2011).

Nilai hematokrit tertinggi terdapat pada perlakuan (A) kepadatan 3.000 ekor $/ \mathrm{m}^{3}$ (44,37\%); selanjutnya kontrol $1.500 \mathrm{ekor} / \mathrm{m}^{3}(40,00 \%$; dan yang terendah terdapat pada perlakuan kepadatan $4.500 \mathrm{ekor} / \mathrm{m}^{3}$ $(36,14 \%$. Nilai hematokrit pada ikan teleostei berkisar antara 20\%30\%dan pada beberapa spesies ikan laut sekitar 52,05\%(Jawad et al., 2004). Hasil pemeriksaan terhadap hematokrit dapat dijadikan sebagai salah satu patokan untuk menentukan keadaan kesehatan ikan. Penurunan nilai hematokrit pada perlakuan B dapat diakibatkan oleh penurunan mutu air yang membuat ikan menjadi stres dan perubahan kondisi lingkungan. Hal ini sejalan dengan Ardiansyah \& Fotedar (2015) bahwa perubahan kadar hematokrit dapat dipengaruhi oleh dua faktor, yaitu perubahan parameter lingkungan, serta keadaan fisiologis ikan. Pada perlakuan $A$, persentase hematokrit paling tinggi di antara perlakuan lainnya yang merupakan kondisi yang optimum untuk pendederan ikan kakap putih sistem RAS.

\section{Analisis Usaha}

Analisis usaha untuk menilai sejauh mana manfaat yang dapat diperoleh dalam melaksanakan suatu kegiatan usaha. Hasil analisis usaha dari pendederan kakap putih dengan sistem RAS ini digunakan sebagai bahan pertimbangan dalam mengambil keputusan dengan memperhitungkan biaya yang digunakan terlihat pada Tabel 4. 
Tabel 3. Nilai hematokrit pada ikan kakap putih, L. calcarifer yang dipelihara di sistem RAS dengan kepadatan berbeda

Table 3. Hematocryte value of barramundi juvenile, L. calcarifer during the experiment

\begin{tabular}{cc}
\hline Perlakuan (Treatments ) & $\begin{array}{c}\text { Nilai rata-rata hematokrit } \\
\text { Average value of haematocrit }(\%)\end{array}$ \\
\hline A $\left(3,000\right.$ ekor $\left.(\mathrm{fish}) / \mathrm{m}^{3}\right)$ & $44.37 \pm 4.56$ \\
$\mathrm{~B}\left(4,500\right.$ ekor $\left.(\mathrm{fish}) / \mathrm{m}^{3}\right)$ & $36.14 \pm 5.39$ \\
$\mathrm{C}\left(1,500\right.$ ekor $\left.(\mathrm{fish}) / \mathrm{m}^{3}\right)$ & $40.00 \pm 4.86$ \\
\hline
\end{tabular}

Tabel 4. Analisis usaha pendederan benih ikan kakap putih dengan sistem RAS sederhana Table 4. Business analysis of barramundi nursery using a simple RAS system

\begin{tabular}{|c|c|c|c|c|}
\hline \multirow[b]{2}{*}{ No. } & \multirow[b]{2}{*}{$\begin{array}{c}\text { Uraian } \\
\text { Description }\end{array}$} & \multicolumn{3}{|c|}{ Perlakuan (Treatments) } \\
\hline & & $\begin{array}{c}\text { A } \\
(3,000 \text { ekor/ind. })\end{array}$ & $\begin{array}{c}\text { B } \\
(4,500 \text { ekor/ind. })\end{array}$ & $\begin{array}{c}\text { C } \\
\text { (sirkulasi/circulation } \\
1,500 \text { ekor/ind.) }\end{array}$ \\
\hline
\end{tabular}

1 Biaya tetap (Fixed cost):

a. Penyusutan (Depreciation):

- Bak fiber (Fibre tank)

- Pompa (Pump)

- Blower

- Skimmer

- Instalasi air (Water instalation)

- Instalasi listrik (Electricity instalation)

- Filter bag dan lain-lain (Filter bag etc.)

- Sewa lahan (Leasing land)

b. Bunga modal (Capital interest)

2 Biaya variabel (Variable cost):

a. Benih (Seeds)

b. Pelet (Pellets)

c. Langganan daya (Electricity)

d. Obat dan vitamin (Medicines and vitamin)

e. Analisis kualitas air (Water quality analysis)

f. Biaya lainnya (Others)

g. Tenaga kerja (Labor)

3 Total biaya produksi (Total Production cost)

Total biaya (Total cost) (Rp)

Produksi (ekor) sintasan (SR)

Production (ind.) survival rate (SR)

Harga produksi (Production cost) ((Rp)/cm)

Pendapatan kotor (Gross production) (Rp)

Pendapatan bersih (Net income) (Rp)

$\mathrm{R} / \mathrm{C}$ rasio ( $\mathrm{R} / \mathrm{C}$ ratio )

$\begin{array}{rrr}240.000 & 240.000 & 2.000 .00 \\ 195.000 & 195.000 & 150.000 \\ 34.375 & 34.375 & 250.000 \\ 440.000 & 440.000 & - \\ 85.063 & 85.063 & 358.000 \\ 7.500 & 7.500 & 75.000 \\ 29.050 & 29.050 & 222.200 \\ 225.000 & 225.000 & 450.000 \\ 248.017 & 248.017 & 295.308\end{array}$

9.000 .000

13.500 .000

4.500 .000

6.440 .000

10.905 .000

3.220 .000

3.500 .000

3.500 .000

500.000

195.000

210.000

195.000

180.000

180.000

450.000

450.000

1.000 .000

1.800 .000

3.600 .000

22.269 .004

32.049 .004

15.815 .508

23.773 .008

33.553 .008

19.616 .017

8.640

12.960

7.380

400

400

400

25.920 .000

34.732 .800

1.179 .792

20.664 .000

2.146 .992

1.09 
Pendapatan usaha yang besar tidak selalu mencerminkan tingkat efisiensi usaha yang tinggi. Usaha pendederan ikan kakap putih dengan sistem RAS sederhana ini dapat dinyatakan layak atau masih dalam tingkat efisiensi apabila nilai $\mathrm{R} / \mathrm{C}$ rasio lebih dari satu yang artinya nilai penerimaan sama lebih besar dari total biaya, maka semakin besar nilai $R / C$ rasio maka semakin besar pula tingkat efisiensi suatu perusahaan (Salim et al., 2013). Nilai R/C rasio usaha pada penelitian ini per siklus > 1 yang menunjukkan bahwa kelayakan ekonomis usaha pendederan sistem RAS layak untuk diusahakan. Namun demikian upaya perbaikan sistem resirkulasi perlu dikaji sehingga dapat meningkatkan sintasan benih.

\section{KESIMPULAN}

Aplikasi sistem resirkulasi (RAS) pada pendederan ikan kakap putih dapat dilakukan dengan penerapan kepadatan 3.000 ekor $/ \mathrm{m}^{3}$. Namun demikian sistem resirkulasi dapat diterapkan pada kegiatan produksi benih ikan kakap putih secara massal dengan beberapa penyempurnaan dari sistem RAS tersebut.

\section{UCAPAN TERIMA KASIH}

Penelititan ini dibiayai oleh DIPA BBRBL-PP Gondol, Bali Tahun Anggaran 2018. Penulis mengucapkan terima kasih kepada Ibu Prof. Dr. Haryanti atas segala masukan dan dukungan pada penelitian ini, serta seluruh staf teknisi bioteknologi atas segala bantuan selama berlangsungnya penelitian ini.

\section{DAFTAR ACUAN}

Ardiansyah \& Fotedar, R. (2015). Water quality, growth and stress responses of juvenile barramundi (Lates calcarifer Bloch), reared at four different densities in integrated recirculating aquaculture systems. Aquaculture, DOI: 10.1016/ j.aquaculture.2016.03.001.

Chen, S., Coffin, D.E., \& Malone, R.F. (1997). Sludge production and management for recirculating aquacultural systems. Journal of the World Aquaculture Society, 28(4), 303-315.

Drengstig, A. \& Bergheim, A. (2013). Commercial landbased farming of european lobster (Homarus gammarus L.) in recirculating aquaculture system (RAS) using a single cage approach. Journal of Aquacultural Engineering, 53, 14-18.

El-sayed, A. \& Mamdouh, K. (2008). Optimum water temperature boosts the growth performance of nile tilapia (Oreochromis niloticus) fry reared in a recycling system. Aquaculture Research, 39, 670672. DOI: 10.1111/j.1365-2109.2008.01915.x.
Fitriadi, F. \& Nurmalina, R. (2008). Anal isis pendapatan dan pemasaran padi organik metode system of rice intensification (SRI): Kasus di Desa Sukagalih Kecamatan Sukaratu Kabupaten Tasikmalaya. Jurnal Pengkajian dan Pengembangan Teknologi Pertanian, 11(1), 94-103.

Fairchild, E. \& Howell, W. (2001). Optimal stocking density for juvenile winter flounder, "Pseudopleuronectes americanus." Journal of the World Aquaculture Society, 32(3), 300-308.

Gullian-Klanian, M. \& Arámburu-Adame, C. (2013). Performance of nile tilapia Oreochromis niloticus fingerlings in a hyper-intensive recirculating aquaculture system with low water exchange. J. Aquat. Res., 41(1), 150-162.

Helfrich, L.A. \& Libey, G. (1990). Fish farming in recirculating aquaculture systems (RAS). Department of Fisheries and Wildlife. Sciences, Virginia Tech, New York.

Jawad, L.A., Al-Mukhtar, M.A., \& Ahmed, H.K. (2004). The relationship between haematocrit and some biological parameters of the Indian shad, Tenualosa ilisha (Family Clupeidae). Animal Biodiversity and Conservation, 27(2), 47-52.

Li, X. , Liu, Y., \& Blancheton, J.P. (2013). Effect of stocking density on performances of juvenile turbot (Scophthalmus maximus) in recirculating aquaculture systems. Chinese J. Oceanol. Limnol., 31, 514522.

Malone, R. (2013). Recirculating aquaculture tank production systems. A review of current design practice. Southern Regional Aquaculture Center (SRAC) Publication, No. 453, 11 pp.

Riche, M., Weirich, C.R., \& Wills, P.S. (2013). Stocking density effects on production characteristics and body composition of market size cobia, Rachycentron canadum, reared in recirculating aquaculture systems. J. World Aquacult. Soc., 44, 259-266.

Salim, S.S., Ignatius, B., Suresh V.K., Pushkaran K.N., Salini, K.P.R., \& Abhilash, P.R. (2013). Economic analysis on the hatchery technology and growout of pearl spot (Etroplus suratensis). Journal of Fisheries, p. 1-20.

Sharma, J. \& Chakrabarti, R. (2003). Role of stocking density on growth and survival of Catla, Catla catla, and Rohu, Labeo rohita, larvae and water quality in a recirculating system. J. App. Aquaculture, 14, 171178.

Schreier, H.J., Mirzoyan, N., \& Saito, K. (2010). Microbial diversity of biological filters in recirculat- 
ing aquaculture systems. Curr. Opin. Biotechnol., 21, 318-325. DOI: 10.1016/j.copbio.2010.03.011. PubMed: 20371171.

Shiver, N.B. \& Grove, T. (2011). Hematocrit and hemoglobin determination in the mangrove killfish, Kryptolebias marmoratus. Georgia Journal of Science, 69(4), 123-130.

Timmons, M.B., Ebeling, J.M., Wheaton, F.W., Summerfelt, S.T., \& Vinci, B.J. (2002). Recirculat- ing aquaculture systems. New York: Cayuga Aqua Ventures, Ithaca. NRAC Publication (Second Ed.).

Timmons, M.B. \& Ebeling, J.M. (2007). Recirculating aquaculture. Northeastern Regional Aquaculture Center (NRAC) Publication \#01-007, Michigan State University, Lansing.

Zonneveld, N.E., Huisman, A., \& Boon, J.H. (1991). Prinsip-prinsip budidaya ikan. Jakarta: Gramedia Pustaka Utama, $318 \mathrm{hlm}$. 